\title{
Media Coverage of the Stormy Weather in Romania in September 2017
}

\author{
Prof. Delia Cristina BALABAN, PhD \\ Faculty for Political, Administrative, and Communication Science \\ Babeș-Bolyai University, Cluj-Napoca, Romania \\ Email: balaban@fspac.ro
}

\begin{abstract}
In the context of climate change, unusual stormy weather has become a highly recurrent phenomenon. These kinds of events usually generate plenty media coverage. The article focused on media coverage of the stormy weather events that took place mid-September in Romania. In this particular case, the author will also analyze the way decision-makers in the capital city reacted, based on the messages that where disseminated on SNS. Using Framing Theory as a background for the present research, the methodology is based on content analysis of Romanian newspapers (both quality papers and tabloids), and of Romanian news portals related to news channels.
\end{abstract}

Keywords: Framing theory; Stormy weather; Media coverage.

\section{Introduction}

From an audience standpoint, the weather forecast has been one of the most important functional information that the media is providing nowadays. People use radio, television, and mainly applications on smartphones and tablets to keep constantly informed about the weather. This growing interest is not only caused by medialization processes, which means that in general the media are playing a much more important role both within the society and on each individual, but also by the rapid climate changes, impacting more or less on each and every corner of the Earth. Unusual weather phenomena also represent a focus point of the media. 
Research on media communication effects has almost always been a point of interest for researchers, not only coming from the field of communication sciences, but also from fields such as sociology, psychology (Dobrescu \& Bârgăoanu, 2003; Dobrescu, Bârgăoanu \& Corbu 2007). This constant interest for researching media effects is caused by at least two aspects. Firstly, media is always undergoing changes, with the Internet, smartphones, and social networks being only some of the structures that have appeared and developed during the last few years. Secondly, media reception is also changing, as youth nowadays have completely different media socialization backgrounds than older generations. Just by taking a short look on media habits of the young generation worldwide we can become aware of this transformation process. These two phenomena - on the one hand the media change, and on the other hand the changing patterns in media use - turn media effect research into a constantly current topic (Balaban 2014). Hence, the re-evaluation and re-interpretation of classical theories on media effects could be developed to a relevant topic.

The aim of this article is to apply framing theory on events that took place in Romania, in September 2017, regarding some special weather phenomena, in order to spot the differences in reporting on this issue, based on media typologies.

\section{Theoretical background}

Framing theory is one of the most prolific theories in terms of applied research within the last decades, in the communication science, but not limited to this field. From sociology and psychology (Goffman, 1974), mass communication (Entman 1993; Gamson \& Modigliani 1989), to political communication (De Vreese 2005), and even to public relations (Dan \& Ihlen 2011), schools of research have developed studies in their effort to understand how frames work.

Framing theory is based on the assumption that the way in which a piece of news is presented by the media carries an influence on the way in which the public receives it. In order to effectively structure information, individuals use interpretative schemes, the so-called frames, that function as cognitive, interpretative structures in the mind of journalists or in that of receivers; in the case of media, these structures bear the role of contributing to processes of information selection and presentation. The frames, thus, are selective points of view on topics and events (Balaban 2009; 2014).

The framing phenomenon is complex, as literature postulates framing by selecting topical aspects, framing by internal structuring, framing by creating links between several aspects of the issue and framing by external contextualization, by creating links with other issues, which in the field is called frame-bridging (Jäckel 2008, p. 185). Most research focuses on two types of frame definitions: the first one is presenting framing in very general terms, while the second one underlines 
exactly what frames do, including references both to its constituent elements, and the types of messages they convey. The present study focuses only on media frames (Scheufele 1999). Framing has a selective function by emphasizing particular aspects of reality, and hiding others. Subsequently, a certain point of view is being suggested to the audience.

Frames are used by three types of actors: by decision-makers - to define political opinions -, by journalists - to present complex event in an accessible manner for the public -, and nevertheless, by the public - to make sense of the media messages. According to Entman (2003), there is a frame competition owed to every actor emphasizing their point of view, wanting the audience to accept the frame that they is supporting or advancing. Similarly, every frame includes these four elements: problem definition, causal analysis, moral judgment, and solution proposal (Entman 1993).

Defined as patterns of interpretation, frames can be generic specific (Iyengar 1991), issue-specific news frames (Entman 1993), and valence news frames (DeVreese \& Boomgaarden 2003). The valence news frames are used in the research of political communication in the sense that they allow judgment of value; a political measurement can be assessed in terms of good or bad. Emphasizing the concept of media credibility, the framing theory implies the fact that the way news is presented influences the way the audience perceives it (Balaban 2008).

\section{Methodology}

The main goal of this research is to identify the frames that are emphasized by the media with respect to the bad weather in September 2017, in Romania, taking into consideration the complexity of integrating several factors like institutional factors, the particularity of SNS, etc.

The research questions are:

1. What frames can be identified related to the stormy weather in Romania, between September $17^{\text {th }}$ and the $20^{\text {th }} 2017$ ?

2. How and when were the opinions of experts reflected in the media, during those events that took part in Romania?

3. Are there differences between the media coverage of the events presented by the quality papers versus that delivered by the tabloids?

4. To what extent has the context influenced the reaction of the Bucharest municipality regarding the measures that were taken for the safety of the population on September 20 ${ }^{\text {th }}$ 2017? (By context, we understand the global weather disasters that occurred in the days before such as the storms Harvey and Irma, the storm that took place in Timisoara on Sunday, September $17^{\text {th }} 2017$.)

The research method employed in carrying out the present research is content analysis. The online editions of the main Romanian quality newspapers Adevarul, 
Jurnalul național, Cotidianul, the Romanian tabloids Click, Cancan, Libertatea, and the main Romanian online news sites Realitatea.net, Digi24.ro where put under a scientific lens. I used the online editions not only because of their accessibility, but also because the online editions are much larger and contain more articles than the print editions. In terms of audiences, the number of online users is also larger than the number of newspaper copies. The sample encompassed quality papers, but also tabloids, because of the popularity of the latter, and because I expected to see some differences in terms of media coverage of the events, due to different media typologies. Lastly, the online news sites are related to two main news televisions in Romania, and television still represents the mainstream media, at least for a category of population that is older than 35 years. We identified a number of $35(\mathrm{~N}=35)$ articles related to the storm and its aftermath that where published between September 17 and September 21, 2017. Additionally, I analyzed the message that was disseminated on SNS on September 20, 2017 with respect to a strong storm that is coming towards Bucharest.

\section{The events}

Sunday, September 17, 2017, a storm caused serious damage to the western part of Romania, especially the Arad and Timisoara counties. As a result, eight people lost their lives and hundreds (the number of injured people is different according to different sources) were injured. Over 260,000 houses had no electricity for a period of time. On September 20, 2017, a storm affected Bucharest and other regions in the southern part of Romania. One person died and several were injured. Previously, on that day, several weather warnings were issued. The unusual thing was that a message saying that the major of the capital city is hiding the real threat of the stormy weather that is approaching, sped over SNS, Whatsapp, SMS. Mayor Gabriela Firea went public on a press conference denying the information in the message, announcing that she would bring its authors to justice. Meanwhile, she imposed the closing of schools at 5 p.m., forcing thousands of parents to leave their jobs earlier in order to pick the children from the school. Traffic in the capital city was almost blocked. The mayor also launched a warning regarding the danger caused by trees and outdoor advertising that could flow over due to the wind. Compared to the storm in the western part of Romania and especially in Timisoara, the storm in Bucharest was causing less damage. One person lost his life in Bucharest during the stormy weather, there were some casualties, and the mayor was criticized - especially online - for her overreaction and the traffic chaos generated. The critics of the mayor created a Wikipedia site under the name Extra tropical Cyclone Gabi, as a satirical reaction. 


\section{Findings}

Romania is a country that does not record extreme weather conditions on regularity. Thus, unusual weather situations such as storms have been occurring much often in the last years, which is why the audiences have become increasingly more sensitive to these issues. The pictures of the tropical storms Irma and Harvey that affected islands in the Caribbean Sea and on the U.S. coast were still present in the minds of the Romanian audiences, and of the public authorities at the time the stormy weather affected Romania, mid-September 2017. The results of the content analysis are presented in relation to the research questions:

1. What frames where presented: the September 17 storm was characterized by the tabloid media and by the realitatea.net news portal with words such as: "nature catastrophe" or "apocalyptical pictures." Even the news portal digi24.ro described the events as "the pictures of the disaster" and "terrifying pictures." No comparison was made with the events that took place overseas. In terms of valence news frames, we identify, on the one hand, the idea that the local administration of Timisoara is responsible for some of the casualties, and on the other hand, the mayor of Timisoara went public saying the opposite. The weather took them by surprise; it is very difficult to predict nowcasting weather events. The entrance to the city of Timisoara collapsed over a car that was being driven by a young student, who became a casualty. Even with respect to that, the municipality took no responsibility, claiming that they only consolidated the monument two years ago, whereas this symbol of Timisoara was built during Ceausescu's time. One can only formulate the hypothesis that the reaction of the Bucharest mayor on September 20, 2017 was strongly influenced by the events from the western part of the country, but this is nearly impossible to prove. There where voices that claimed that there was an overreaction of the mayor, this frame was emphasized especially in the social media, mostly in a satirical way. On the following day, the leader of the leading party (to which the mayor is affiliated) expressed his support for the mayor's measurements (Libertatea, 21.09.2017).

2. The opinions of the experts where quoted in a large proportion (10) of the articles that where analyzed. Nevertheless, the quality newspapers and the news portals tended to present experts opinion (9 out of 10). With respect to the ongoing bad weather on September 20, some of the web sites even presented the weather warnings from the National Authority for Meteorology and Hydrology $(A N M H)$ on a map in real time.

3. There are differences between media coverage in the quality newspapers and media coverage in tabloids. The language of the tabloids is also different, in that they use a much more descriptive way of presenting the events. Pictures were much more present in the tabloids than in the quality papers. One picture was particular used: that of the symbol of Timisoara, the city gate that collapsed and 
crushed a car that was passing on September 17, 2017, killing a young stomatology student from the University for Medicine and Pharmacy. The tabloids even tried to personalize the face of the damages by telling the story of this young victim.

4. Regarding the role of the context in the article I analyzed, the storms Irma and Harvey were not mentioned, but in the news issued on September 20 and 21, the events from Timisoara were mentioned. The storm in Timisoara was an unusual phenomenon that leads to several discussions of whether the municipality took every necessary means to avoid casualties.

To figure out how a warning system functions in Romania in case of nature catastrophes, an interview that the Minister for Internal Affairs gave to DigiTV, that was available on digi24.ro, was analyzed. According to Minister Carmen Dan, the process of notifying the public about such events starts with the National Institute for Meteorology and Hydrology sending a warning to the Ministry, then the central institution is sending warnings to the local public administration, particularly to Emergency Inspectorate (Inspectoratul pentru Situații de Urgență, ISU). From this particular point, every county ISU has its means to inform the population. Nevertheless, the nowcasting warnings are difficult to reach the population through other means than the media. It is a complicated issue. In well-developed regions, the warnings can be released on special apps that the majority of the population is using. This is not the case in Romania, not even in the big cities.

\section{Conclusion}

By using content analysis, all of the research questions found answers. The storm weather from September 17, 2017 in the western part of Romania had rich media coverage, and its aftermath was presented in a dramatic manner, especially by the tabloids. These events were the cause for a certain sensitivity that both media and the politicians experienced in the following days. This is the context that contributed to the diffusion of the panic message through SNS, Whatsapp and SMS.

This study has an exploratory nature, and due to the limits of the sample, the results cannot be subject to generalization. Thus, the tendencies reflected can be taken into consideration for further research.

\section{References}

1. Balaban, D. C. (2008). The Framing or the Interpretation Frames Theory. Journal of Media Research, 8-12.

2. Balaban, D. C. (2009). Comunicare mediatica. București: Tritonic.

3. Balaban, D.C. (2014). Perspectives on Media and Advertising Research. Cluj-Napoca: Accent. 
4. Dan, V., Ihlen, Ø. (2011). Framing Expertise. A Cross-Cultural Analysis of Success in Framing Contests. Journal of Communication Management, 15(4), 368-388.

5. De Vreese, C. H. (2005). News framing: Theory and typology. Information Design Journal + Document Design, 13(1), 51-62.

6. De Vreese, C. H., Boomgaarden, H. (2003). Valenced News Frames and Public Support for the EU: Linking Content Analysis and Experimental Data. Communication, 3(4), 361-381.

7. De Vreese, C. H., Boomgaarden, H. (2006). How content moderates the effects of television news on political knowledge and engagement. Acta Politica: International Journal of Political Science, 41, 317-341.

8. Dobrescu, P., Bârgăoanu, A. (2003). Mass-media și societatea. București: comunicare. ro.

9. Dobrescu, P., Bârgăoanu, A., Corbu, N. (2007). Istoria comunicării. București: comunicare.ro.

10. Entman, R. M. (1993). Framing: Toward Clarification of a Fractured Paradigm. Journal of Communication, 43(4), 51-58.

11. Entman, R. M. (2003). Cascading Activation: Contesting the White House's Frame After 9/11. Political Communication, 20, 415-432.

12. Gamson, W. A., Modigliani, A. (1989). Media Discourse and Public Opinion on Nuclear Power. A constructionist approach. American Journal of Sociology, 95, 1-37.

13. Goffman, E. (1974), Frame Analysis: An Essay on the Organization of Experience. New York: Harper \& Row.

14. Iyengar, S., Simon, A. (1993). News Coverage of the Gulf Crisis and Public Opinion. Communication Research, 20, 365-383.

15. Jäckel, M. (2008). Medienwirkungen. Ein Studienbuch zur Einführung, $4^{\text {th }}$ edition. Opladen: Westdeutscher Verlag.

16. Scheufele, D. A. (1999). Framing as a Theory of Media Effects. Journal of Communication, 103-122. 